\title{
Long-term Oncologic Outcomes of Obesity after Laparoscopic Surgery for Colorectal Cancer in Asian Patients
}

Se-Jin Baek, M.D., Ph.D.

Division of Colorectal Surgery, Department of Surgery, Korea University College of Medicine, Seoul, Korea

Corresponding author

Se-Jin Baek

Division of Colorectal Surgery, Department of Surgery, Korea University College of Medicine, Inchon-ro 73, Seongbuk-gu, Seoul 02841, Korea

Tel: +82-2-920-6268, Fax: +82-2-928-1631, E-mail: xezin@korea.ac.kr

This is an Open Access article distributed under the terms of the Creative Commons Attribution Non-Commercial License (http:/l creativecommons.org/licenses/by-nc/4.0/) which permits unrestricted non-commercial use, distribution, and reproduction in any medium, provided the original work is properly cited.
Copyright (C) 2016 The Journal of Minimally Invasive Surgery. All rights reserved.
일반적으로 비만은 수술 후 단기 결과에 나쁜 영향을 미치는 것으로 알려져 있다. 비만 환자에서는 수술 시간이 길어지고, 상 처 관련 합병증과 수술 후 재원 기간이 증가하며, 복강경 수술 의 경우 개복 전환률이 높다. ${ }^{1-3}$ 이러한 수술 후 열등한 단기 결 과는 의료 비용을 증가시키며, 이것은 전체적인 의료-사회적 비 용 증대로 이어진다. 한편 비만이 수술 후 장기 생존 결과에 미 치는 영향에 대해서는 아직까지 논란이 있다. ${ }^{3-5}$ 이러한 연구들 이 대부분 서구에서 이루어진 것으로 동양인에서의 연구는 아 직까지 미흡한 실정이다. 이에 동양인에서는 비만이 수술 후 장 기 생존 결과에 어떠한 영향을 미치는지에 대한 질문으로부터 저자들의 논문은 시작되고 있다. 특히 최근 식생활이 서구화되 면서 우리나라에서도 비만 환자가 크게 증가하고 있고 ${ }^{6}$ 비만과 관련성이 높은 대장암의 경우 비슷한 증가 추세를 보이고 있는 데, 저자들이 대장암, 이중에서도 최근에 널리 사용하고 있는 수술법인 복강경 수술을 받은 대장암 환자를 중심으로 비만이 장기 생존 결과에 미치는 영향에 대하여 분석을 시행한 것은 시 의 적절한 연구 주제라 할 수 있겠다.

복강경 수술의 경우 비만 환자에서 발생할 수 있는 수술 후 단기 합병증이 상대적으로 적을 뿐 아니라, 수술 중 환자에게 가해지는 스트레스 및 면역계의 영향 등과 관련하여 장기 생 존 결과에도 긍정적인 영향을 미칠 수 있을 것으로 기대되고 있
다. ${ }^{70}$ 저자들은 결과에서 비만 환자군과 정상 체중 환자군에서 의 장기 생존 결과에 차이가 없음을 보여주었는데, 이러한 결과 가 수술 방법에 의한 영향이 아닌 온전히 내재적인 원인만으로 설명하기 위해서 개복 수술을 받은 환자를 대상으로 하는 연구 가 동시에 이루어졌으면 좀 더 설득력을 얻을 수 있었을 것으로 생각된다. 더불어 비만 환자군과 정상 체중 환자군에서 기저질 환의 동반 정도나 대장암의 발생 부위에 차이가 있어 결과의 해 석에 주의를 요한다. 다만 비만의 기준을 세계보건기구(World Health Organization, WHO)의 권고를 참조하여 서양보다 낮은 체질량 지수(body mass index, BMI)인 $25 \mathrm{~kg} / \mathrm{m}^{2}$ 로 적용하였음 에도 불구하고 비만 환자군이 $23.3 \%$ 로 정상 체중 환자군보다 훨씬 적게 포함이 되어있는 상태에서, 이러한 변수들을 모두 통 제했을 때 연구에 포함되는 환자 수가 크게 감소하여 실질적으 로 분석을 시행하기에 어려움이 있었을 것임은 충분히 이해가 가는 바이며, 이는 아마도 우리나라에서 비만에 대한 연구를 시 행할 때의 연구자가 겪는 공통적인 어려움일 것이다.

본 연구에서는 비만 여부를 판단하는 지표로 $\mathrm{BMI}$ 를 이용하 였는데 BMI가 전신 합병증과 연관성이 높은 복부 비만을 잘 반 영하지 못하여, 복부 비만도를 좀 더 잘 반영한다고 알려져 있 는 지표들, 예를 들어 허리-엉덩이 비(waist hip ratio, WHR) 혹 은 허리-신장 비(waist height ratio, WHtR), 복부 전산화 단층 
영상(computed tomography, CT), 전신 이중 에너지 방사선흡수 계측기(dual-energy X-ray absorptionmetry, DXA)와 같은 방법 들을 이용하여 비만도를 측정하여 연구를 시행해 보았어도 좋 지 않았을까 한다. ${ }^{11,12}$ 특히 복부 $\mathrm{CT}$ 를 이용한 복부 비만의 측정 법의 경우 대장암 수술을 시행하는 환자에서 수술 전에 일률적 으로 복부 CT를 시행하므로 분석을 위해 획득할 수 있는 자료 도 풍부하므로 추가적인 연구를 계획할 때 고려해 봄직하다. 본 연구에서는 복강경으로 대장암 수술을 받은 동양 환자에서 비 만이 장기 생존 결과에 영향을 미치지 않았으나 추가적인 연구 의 가능성과 필요성은 여전히 유효하며, 추후 심화 연구를 시행 하는데 있어 근거가 되는 선행 연구로서 본 연구는 매우 의미 있을 것으로 생각된다.

\section{REFERENCES}

1) Mustain WC, Davenport DL, Hourigan JS, Vargas HD. Obesity and laparoscopic colectomy: outcomes from the ACS-NSQIP database. Dis Colon Rectum 2012;55:429-435.

2) Vignali A, De Nardi P, Ghirardelli L, Di Palo S, Staudacher C. Short and long-term outcomes of laparoscopic colectomy in obese patients. World J Gastroenterol 2013;19:7405-7411.

3) Makino T, Trencheva K, Shukla PJ, et al. The influence of obesity on short- and long-term outcomes after laparoscopic surgery for colon cancer: a case-matched study of 152 patients. Surgery 2014; 156:661-668.

4) Singh A, Muthukumarasamy G, Pawa N, Riaz AA, Hendricks JB, Motson RW. Laparoscopic colorectal cancer surgery in obese patients. Colorectal Dis 2011;13:878-883.
5) Denost Q, Quintane L, Buscail E, Martenot M, Laurent C, Rullier E. Short- and long-term impact of body mass index on laparoscopic rectal cancer surgery. Colorectal Dis 2013;15:463-469.

6) Kim CS, Ko SH, Kwon HS, et al. Prevalence, awareness, and management of obesity in Korea: data from the Korea national health and nutrition examination survey (1998-2011). Diabetes Metab J 2014;38:35-43.

7) Whelan RL, Franklin M, Holubar SD, et al. Postoperative cell mediated immune response is better preserved after laparoscopic vs open colorectal resection in humans. Surg Endosc 2003;17:972978.

8) Wichmann MW, Huttl TP, Winter $\mathrm{H}$, et al. Immunological effects of laparoscopic vs open colorectal surgery: a prospective clinical study. Arch Surg 2005;140:692-697.

9) Lacy AM, Delgado S, Castells A, et al. The long-term results of a randomized clinical trial of laparoscopy-assisted versus open surgery for colon cancer. Ann Surg 2008;248:1-7.

10) Kennedy GD, Heise C, Rajamanickam V, Harms B, Foley EF. Laparoscopy decreases postoperative complication rates after abdominal colectomy: results from the national surgical quality improvement program. Ann Surg 2009;249:596-601.

11) Shuster A, Patlas M, Pinthus JH, Mourtzakis M. The clinical importance of visceral adiposity: a critical review of methods for visceral adipose tissue analysis. Br J Radiol 2012;85:1-10.

12) Bener A, Yousafzai MT, Darwish S, Al-Hamaq AO, Nasralla EA, Abdul-Ghani M. Obesity index that better predict metabolic syndrome: body mass index, waist circumference, waist hip ratio, or waist height ratio. J Obes 2013;2013:269038. 